\title{
INNOVATION IN OPERATIONS AND PROJECT DEVELOPMENT STRATEGY AT PHE ONWJ TO SUSTAIN THE BUSINESS IN IMPLEMENTING GROSS SPLIT PRODUCTION SHARING CONTRACT
}

\author{
Nanang Sahroini' ${ }^{1}$, Aries Firman ${ }^{2}$ \\ 1 MBA Program MBA of School of Business and Management -Institut Teknologi \\ Bandung (nanang.sahroini@sbm-itb.ac.id) \\ 2 Ph.D. Program of Curtin University of Technology, Australia (aries.firman@sbm- \\ itb.ac.id)
}

\begin{abstract}
Oil \& gas companies in Indonesia are facing a new challenge since the government changed the production sharing contract (PSC) from Cost Recovery scheme become Gross Split scheme through Ministerial Decree of ESDM No. 8/2017 and No. 52/2017, 'Kontrak Bagi Hasil Gross Split'. The biggest challenge in new scheme is Company must bear all the capital cost and risk instead of Company and Government proportionally.

In the way to get the research objectives in finding out key factors potential cause of failure the gross split implementation at PHE ONWJ and it's strategy to avoid the failure, author performed the research by qualitative method referred to Creswell research methodology through individual interview of 10 experts in oil \& gas industry. The scope of the paper is study literature, observation, individual interview, data analysis, finding and discussion, recommendation, and implementation plan.

The research found out that key factor of potential failures the gross split implementation is the cost efficiency, which is driven by inefficiency activities, unmanaged risks, and unmanaged cash flow. If Company could not reach a certain amount cost efficiency that equivalent to expenditure $\leq 48 \%$ of total gross revenue, then definitely it leads to potential failure of Company operations business.

Research analysis said that cost efficiency could be achieved when company succeed reducing the operation expenditure (OPEX) and capital expenditure (CAPEX) by performing innovation strategy such as changing the engineering design to fit-for-purpose, expanded procurement to new resources strategy, renegotiate existing contracts value, developing long term contracting strategies, improving contracts scope become very clear, generating work program prioritization, and improving the synergy of stakeholders.

By doing the mentioned innovation strategies, company has obtained cost efficiency and generated positive cash flow for $1^{\text {st }}$ year of gross split implementation. This is an early
\end{abstract}


indication that the implementation of the gross split scheme could more likely be sustainable in PHE ONWJ.

Keywords: Cost efficiency, gross split, work program priority, cash flow, OPEX \& CAPEX

\section{INTRODUCTION}

Government changed the Production Sharing Contract (PSC) from cost recovery become gross split because government like to encourage Companies performing more efficiency in managing the business. Data from MEMR said that cost recovery had trending increment from 2012 to 2015. Even though it was decreasing at 2016, but production of oil \& gas had a trending decrease. Government saw it should be initiated to find out alternative PSC scheme that facilitated the improvement of efficiency.

The following table shows the trending of cost recovery increment but the other hand it is opposite with the production of oil \& gas.

Table-1: Trending of Cost Recovery Increment vs Oil \& Gas Production

\begin{tabular}{|c|c|c|c|c|}
\hline Description & 2012 & 2013 & 2014 & 2015 \\
\hline Cost Recovery (US\$ 000,000,000) & $\times 15.60$ & 15.90 & 16.30 & 13.70 \\
\hline Production Oil (bopd x 10,000) & 85.97 & 82.42 & 78.88 & 78.58 \\
\hline Production Gas (mmscfd) & 81.96 & 81.30 & 82.18 & 80.78 \\
\hline
\end{tabular}

(Source: ESDM and Laporan Tahunan SKK Migas year 2016)

PT PERTAMINA Hulu Energy Offshore North West Java (PHE ONWJ) as the first Company that implements the gross split in Indonesia. This Company is owned by Pertamina that manages block in Java Sea where previously managed by foreign company BP West Java. The production of this block when it acquired by Pertamina as much as 23,100 BOPD of crude oil and 80 MMSCFD of gas. Since then new development and optimization of projects were done; it's gradually increased the production. By 2014 PHE ONWJ recorded the highest oil and gas production at 
43,000 BOPD and 180 MMSCFD gas. The facilities on ONWJ field has already mature around 40 years old now.

Since the implementation of gross split, Company as executor and the government as regulator have facing very big challenges because they have never had experience in the applying this scheme before. This is one of considerations for author to conduct further research related to the topic. The expectations author performing the research is to get the best solution for the company in implementing Gross Split so it can help company sustaining the business.

In term of earning, gross split scheme is very beneficial for Government because they secure the revenue at the front, the revenue is certain without affected by company expenditure, Government also no longer bear the risk of company activity, and furthermore Government still get additional income from tax of company revenue.

For Company, this scheme is less beneficial comparing to previous regime (cost recovery) because Company net revenue is still uncertain and all risk now is 100\% borne by company. The other aspects that contribute in the uncertain net revenue are the dynamics of market price for service and goods that is depend on world oil price. Procurement process is not necessarily becoming simpler because even though the flexibility is given to company, but Company shall comply with other government regulation that related to procurement such as local content regulation (TKDN), export-import of goods, taxes, and other cost for annual rent for operated facility by company.

Following the above description, it can be seen that the problem statement as a focus in this research is 'How Company could be sustain in facing the challenge of gross split implementation?' If the company does not anticipate this challenge properly then the immediate impact will come to company particularly the financial aspect which is a negative cash flow. Negative cash flow will disrupt the company's business furthermore it leads to failure of company operation business. The business process improvement and innovation is required to answer it. 


\section{METHODS OF PRODUCTION SHARING CONTRACT SPLITTING}

The concept of Gross Split PSC adopts the concept of 'Royalty and Tax' scheme with some exclusive treatment. The difference between the previous cost recovery regime and gross split is the deleting coverage investment and operation cost by Government. All cost and risk now is borne by Company. The following schematic diagram in Figure 1 shows the conceptual framework of splitting method as a difference between Cost Recovery scheme and Gross Split Scheme.

Determination of split portion is regulated at Ministerial Decree of MEMR No. 8/2017 and No. 52/2017 with the following formula and the portion of split parameter as shown at in Appendix-A.

The Gross Split formula is

Company Split $=$ Base Split + Variable Split + Progressive Split + Ministry Discretion

- Base spit Company for oil is $43 \%$

- Base split Company for gas is $48 \%$

Refers to paper issued by Pin sent Masons and Wood Mackenzie (2017) themed Indonesia's New Gross Split PSC, Right Structure Wrong Split, there are some important factors that must be taken in to account in the implementation of gross splits, otherwise it will lead to potential failure in it's implementation:

\section{Existing Cost Recovery Pools}

The amount of money from previous investment that has not recovered yet became Company burden. COMPANY still has remaining US\$453 million of unrecovered costs under the previous Cost Recovery PSC. 


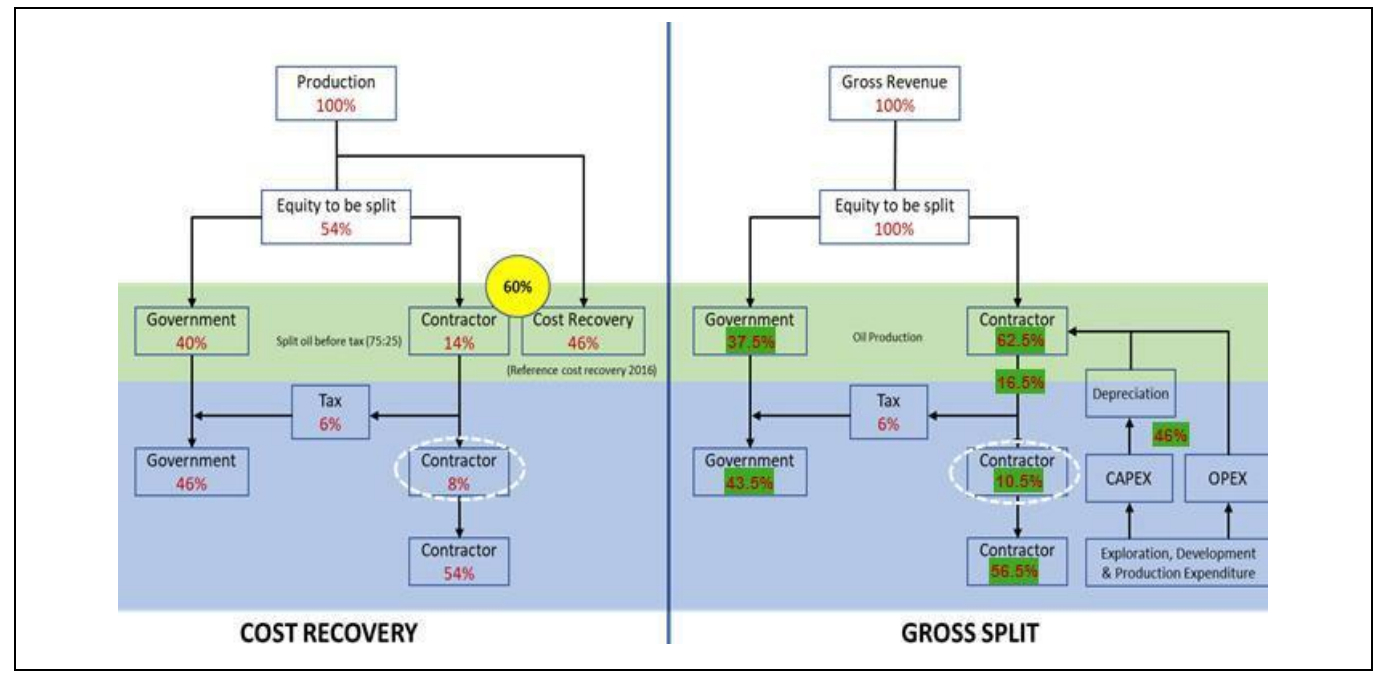

Figure-1: Cost Recovery vs Gross Split

Government finally agree to add 5\% split as a discretion to cover any remaining cost such as existing cost recovery, but Government shall anticipate the lack of clarity on PSC extensions together with the sheer scale of production at risk, make expiring PSCs one of the key issues facing Indonesia's upstream sector.

\section{Increased Company Risks}

Under both types of PSC, exploration risk is shouldered entirely by the Company. However under a Cost Recovery PSC, up on commercial discovery, development, production and abandonment risk is shared with the State through cost recovery. Under the Gross Split regime, all of the risk associated with exploration through to abandonment of the field(s) will now sit with the Company. Whether cheaper and more suitable goods and services can be procured to allow for cost reductions. 


\section{Delay In Return On Investment}

The absence of cost recovery under the new regime means that the Government will have an increased share of oil and gas produced during the early years of production under a Gross Split PSC. It will therefore take longer for the PSC Company to recover its investment costs, leading to increased uncertainty and placing a heavy financial burden on the Company during those early years. The removal of the arduous process of cost recovery should, at least in theory, allow Company's latitude to use more innovative technology and greater discretion in the development of the fields. However cost recovery undoubtedly provides the Company with the ability to de-risk its development and production costs (to some extent).

\section{Oil Prices Related Adjustment}

The Regulation allows for an increased share in the split of production to be awarded to the Company when the ICP is lower than US\$70/barrel, and vice versa during periods when the price is greater than US\$85/barrel. While this provision, taken in isolation, may appeal to investors during periods of lower oil price, it does mean that the gross percentage share of production afforded to the Company will vary on a month to month basis. This could prove to be administratively burdensome.

\section{Regular Adjustment To The Gross Split}

As we know, the gross split percentages between the Company and the Government will be adjusted initially and then on an ongoing basis, based on a number of factors. This will involve a significant amount of discussion between the Company and SKK Migas, may cause uncertainty from the Company's perspective and increase the risk of potential disagreements arising on the adjustments. Further, 
it remains to be seen whether SKK Migas will adopt a consistent approach among different PSC Companies.

Different negotiations, and different negotiators, could lead to different outcomes in practice.

\section{Delay Prior To The Development Stage}

There is also a high likelihood of disagreements arising between the Government and PSC Companies in determining the adjustments to the initial base split, at the point of approval by the Government of the PSC Company's PoD. In coming to an agreement on the adjustments, the determining considerations are likely to include long term assumptions of commodity prices, production volumes and investment and operational costs. Taking into account the long term nature of the oil and gas industry, it will be difficult to determine the long term economic variable assumptions which will be agreeable to both parties.

\section{Ownership Of Asset}

As outlined above, title to goods, equipment and land purchased or acquired by the PSC Company under a Gross Split PSC and directly used in petroleum operations will continue to vest in the State (as was the case with the existing Cost Recovery PSCs). However the cost recovery mechanism (as supported by the Constitution) was always the key justification for this.

\section{Abandonment Cost}

Indonesian PSCs have included an abandonment clause since 1995 which provides that PSC Companies must include in their budgets provisions for clearing, cleaning and restoring the site upon completion of the work. As any funds set aside for abandonment and restoration under the Cost Recovery PSC are cost recoverable once funded or spent, unused funds following decommissioning are transferred to 
SKK Migas. The Regulation is silent on the issue of abandonment, however it seems clear that abandonment costs will no longer be cost recoverable when funded or spent.

\section{Accelerate Procurement Process}

As the procurement process under the new regime will be run independently by the PSC Company and appears to denote a relaxation of the work contract bidding requirements in Indonesia, exploration and other work programmers should in theory be accelerated and technological innovation stimulated. Company shall consider other government regulation that linked to procurement process because it might be constrains to the procurement process it self.

\section{RESEARCH METHODS}

Author performed the qualitative research approach refer to research methodology by of John Cresswell (2007), and complimented by methodology from R Malik \& F Hamid (2016).

The research data consist of primary data and secondary data. Primary data were collected through individual direct interview mechanisms. Secondary data is obtained through hand out of meeting between Company and government body, website, and email. The research involving 10 experts from related oil \& gas industry as respondent. They

represented the group from internal Company and external party to balance the opinion. There are 10 research question that made to dig out the data in answering the research objectives.

\section{Strategy Approach Theory}

Author also refers the strategy frame work from Michael Porter in his book Business Strategy Competitive Advance framework in the way to set up the 
interview protocol with the goal in getting the research objective. The approach of strategy frame work involving cost leadership, differentiation, cost focus, and differentiation focus align with Porter Business Strategy framework.

\section{Data Interpretation}

There are many findings from the interview process as a raw data. To facilitate the process of explaining findings, authors grouping the findings into sub-categories packages. The number of sub-categories based on the grouping of similarities of meaning there are 20 items. Some sub-categories that have similar impact then grouped in to categories, and bigger group of super categories. This grouping is shown in the Appendix - B.

From the spoken frequency during the interview, it shows 8 sub-categories that suspected as Major Issue that contribute much in the cause of failure gross split implementation. Author examined the suspect Major Issue by knowing the impact of each item to the parameters that show the most aspect in the research goal which is a success criteria of gross split implementation.

The criteria was defined from interview process and it found three parameter of success criteria which are:

1. Work program, the success criteria of work program is efficiently.

2. Cash flow, the success criteria is positive cash flow throughout the year.

3. Regulation Government, the success criteria is the consistency government in keeping the regulations not change dramatically.

That means COMPANY will fail in implementing gross split if they gets inefficient work program, negative cash flow, or faces government regulation changes dramatically.

The examine result shows that 8 subcategories are categorized as Major Issue. Author validated this result to related respondents and they confirmed and agreed that 8 sub categories are major issues which leads the failure of gross split 
implementation in the COMPANY. They are Unclear Operation Strategy, Not Synergy Parties, Over Specification/ Design, Conventional Project

Development Strategy, Conventional Contracting Strategy, Uncertain Net Revenue, Changes Government Regulation, Less Priority Multiyear Project, as shown at Appendix-C

\section{RESULT AND DISCUSSION}

The eight major issues are discussed and requesting solutions to answer the research.

\section{Unclear Operation Strategy}

Unclear operation strategy definitely leads to unstructured operation program hence generates waste and bugs in each activity. Some activities that related to operation strategy such as asset management, boat operations management, renting of production facilities, fund reserves for Abandonment and Site Restoration (ASR), and achieving of lower lifting cost.

\section{Not Synergy Parties}

Synergy parties are well-organized collaboration of corporate functions for internal, Extra-Internal and external. The failure of stakeholder management in creating synergy between internal and external parties will disrupt production operations and potentially affect to the failure of gross split implementation in the COMPANY.

\section{Over Specification/Design}

All team from the operational, conceptual engineering, project, external group agreed that the usage of existing specification and design will impact to high cost which contradicts to the spirit of efficiency in the gross split scheme. Hence the high 
cost in project development potentially leads to the failure of gross split implementation.

\section{Conventional Project Development Strategy}

Conventional project development strategy is the management of a project development that focuses on the limited modeling of development scenario. By changing the PSC scheme to gross split that clearly no cost recovery, it is required to have more modeling scenario that considering comprehensive parameters in project development to find the most beneficial scenario to COMPANY.

\section{Conventional Contracting Strategy}

Contracting Strategy is a specific part of the project development stage that represents the business strategy of managing contracting works packages to get the most competitive prices with maximum benefits to COMPANY's.

Conventional contracting strategy focused on creating a service contract by one contract for one service, with a very limited duration and scope on a particular work item.

Conventional contracting strategy affects high cost, less efficiency, long process, and limited flexibility.

\section{Uncertain Net Revenue}

Uncertain Net Revenue is something that represents fluctuation COMPANY gain from it's business which depend on the coverage risk, production volume and market price. Included in the Uncertain Net Revenue are all funding and risks in is covered by COMPANY, gross revenues are dependent on world oil prices that are also uncertain and always volatile, and changing of tax system. 


\section{Changes Government Regulation}

Change Government Regulation is an external factor of company driven by changes and replacements of Indonesian government policies that have a direct impact on COMPANY's business. The Changes Government Regulation tends to cause concern for companies because it can directly change COMPANY's longplanned business schemes.

\section{Less Priority On Multiyear Project}

Gross splits are using their own funds to invest and bear the risks. If the management of the work program is not performed by prioritization it will impact to the bad financial and the company's operations become problematic and potentially failure of the business.

Multiyear Project is a type of corporate projects that are planned to execute sequentially according to priority scale.

\section{INNOVATIVE PROBLEM SOLUTION}

In responding the eight major issues above, the following advised solutions in each major issue. The benchmarking was done to ensure the proposed solution is valid.

\section{Unclear Operation Strategy}

Proposed innovative solutions and the analysis of issue unclear operation strategy.

1. Company to provide abandonment cost reserves (ASR) of lesser amount each year can be done directly by the company. Currently ASR's reserves are US \$ 75 million / year for 20 years. How the reduction of ASR fund reserves can be optimized in the form of a study so that the decommissioning process becomes more effective and cheaper. 
2. Company to select only productive asset facility and operate them to support oil and gas production. Unproductive assets will be returned to the government to reduce the rental cost of production facility.

3. Operation cost and project development cost will be reduced with total commodity cost as much as $45 \%-48 \%$ maximum of gross revenue. They guaranty if it is happened, company will sustain in implementing gross split scheme.

\section{Not Synergy Parties}

Proposed innovative solutions and analysis of the issue of Not Synergy Parties are as follows:

1. Internal synergy with partners by way of renegotiating contract service that support projects and operations are running to get more cost efficiency.

2. External synergy to government through direct report and independent association channel is asking the government to make improvements in the implementation of gross split by finishing the guidance, procedure, and regulation support.

\section{Over Specification/Design}

Proposed innovative solutions and analysis of the issue of over specification/ design are as follows:

1. Conceptual engineering should review the engineering and design specifications until they get a fit for purpose specification by eliminating luxurious on specification, quantity material, and previous designs. The potential cost efficiency of material procurement of this proposal can reach $20 \%$. 
2. Conceptual engineering should propose improve the quality of FEED data hence the project execution using FEED data would efficient without any growth scope.

\section{Conventional Project Development Strategy}

Proposed innovative solutions and the analysis of conventional project development strategy:

1. Project team shall maintain even improve the project execution performance in achieving the high quality target (on time, on budget, on quality, complete safely)

2. Companies should develop more project development modeling scenarios associated with commercial case to find out which scenario is the most optimum for the company. Building a production facility with a suitable production capacity of a small well is not necessarily optimum because the cost of developing an advanced facility will be subject to different treatment from the large split and large taxes.

\section{Conventional Contracting Strategy}

Proposed innovative solutions and the analysis of the issues conventional contracting strategy are as follows:

1. Project team to combine FEED engineering work packages with EPCI work packages. With this strategy, the risk of change order due to changes in the scope of work of the FEED data on the actual results become less even very small. Change order is one of the biggest causes of high cost of an EPCI project.

2. Company to implement a collective and independent procurement strategy by involving subsidiaries under the company holding. Large volume procurement for all subsidiaries will get cheaper unit rates and help cost efficiency at the company holding 
3. Company to encourage the government to grant company more flexible in contracting processes involving other companies in joint contract service. This is to accommodate cost sharing and risk sharing work that requires high cost and has a high failure factor.

\section{Uncertain Net Revenue}

Proposed innovative solutions and the analysis of uncertain net revenue issues are as follows:

1. Gross Split scheme increase Company risk from $15 \%$ to $100 \%$. The biggest risk is in exploration activities so that the risk mitigation of this activity should be fully mitigated with definite calculations. Comprehensive risk mitigation is mandatory to reduce the Company potential loss due to failure of exploration activity.

2. To increase the company's courage to undertake development projects in the frontier area, government should be able to find data in the area. The geological data required by oil and gas companies can be provided by the government by conducting their own survey.

\section{Change Government Regulation}

Proposed solutions and the analysis of change government regulation issues as follows:

1. Government's commitment to keep the block PSC contract for 30 years is expected by investors. If there should be a regulatory change that should be towards improvement and not to be retroactively, and the agreement should be reached with all parties.

2. Government should make detail the split calculation formula that accommodates the complexity of reserve in the subsurface. 


\section{Less Priority On Multiyear Project}

Proposed solutions and the analysis of Less Priority on Multiyear Project issues are as follows:

1. Companies must prioritize operational and project work programs because their budget is limited. The selection is based on the biggest benefit criteria for the company in terms of revenue and value.

2. Company shall have a long-term work program plan. Then they spread out the programs development by rephrasing, rescheduling, so that the outcome will match with financial expectations that is a positive cash flow.

\section{CONCLUSION}

Research results concluded that the main factor causing the failure of gross split implementation in the Company is failure in achieving the COST EFFICIENCY which is driven by 8 major issues in operations and project development: Unclear Operation Strategy, Not Synergy Parties, Over Specification/ Design, Conventional Project Development Strategy, Conventional Contracting Strategy, Uncertain Net Revenue, Changes Government Regulation, Less Priority Multiyear Project.

Gross split implementation will be successful and sustain if Company can achieve cost efficiency with total operating cost (OPEX) and project (CAPEX) of 45$48 \%$ of total gross revenue. If the total cost of OPEX and CAPEX is greater than $48 \%$ then the company's cash flow will be disrupted. The greater the percentage of the cost, the more dangerous the financial company and it might lead to the failure of gross split implementation.

\section{RECOMENDATION}

This research recommends COMPANY to do strategies as listed in the Appendix-D. Some of them has been implemented and it gave an early indication 
that some criteria have been fulfilled such as cost efficiency and positive cash flow.

Out of current implemented strategy, Company should implement the new strategies in the table to increase the sustainability of gross split scheme implementation.

\section{REFERENCES}

Cresswell, J. (2007). Qualitative Inquiry \& Research Design: Choosing Among Five

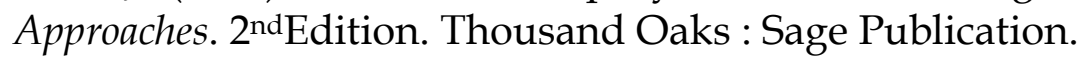

Hand out of presentation Ministry MEMR \& SKK Migas Meeting with PHE ONWJ (6 Jan 2017). Rancangan Gross Split.

Ministry Regulation Energi Sumber Daya Mineral (ESDM) Nomer 8 Tahun 2017. Kontrak Bagi Hasil Gross Split.

Ministry Regulation Energi Sumber Daya Mineral (ESDM) Nomer 52 Tahun 2017. Perubahan Atas Peraturan Menteri Energi Sumber Daya Mineral tentang Kontrak Bagi Hasil Gross Split.

Pinsent Masons and Wood Mackenzie, (2017). Indonesia's New Gross Split PSC, Right Structure Wrong Split.

Appendix-A: Split Portion Parameter

Malik, Rand Hamid, F (2016).Research Method, A Guide for First Time Researchers. Universitas Pendidikan Indonesia: UPI Press.

Porter. Michael E, 2008, Competitive Advance, Creating and Sustaining Superior Performance, Simon and Schuster.

Project Management Institute. (2013). A Guide to The Project Management of Body Knowledge (PMBOK®Guide), $5^{\text {th }}$ Edition. Pennsylvania: Project Management Institute. Inc.

Website CNN Indonesia (cnnindonesia.com, 2 Jun 2017). Menimbang Kemampuan Gross Split Gairahkan Investasi Migas.

Website Industri (industry.bisnis.com, 23 Jan 2017). MIGAS : Pakai Gross Split, Pemerintah Jamin Investor Peroleh IRR 12\%.

Website Kata Data (katadata.co.id, 22 Nov 2017). Skema Gross Split Dinilai Tak Cocok untuk Blok Eksplorasi

VARIABLE SPLIT

\begin{tabular}{|c|l|l|c|}
\hline & & \multicolumn{1}{|c|}{ Type of Incentive } & Additional Split \\
\hline 1 & Block Status & POD I & $5.0 \%$ \\
\hline & & POD II, III & $0.0 \%$ \\
\hline & & POFD & $0.0 \%$ \\
\hline
\end{tabular}




\begin{tabular}{|c|c|c|c|}
\hline & & No POD & $-5.0 \%$ \\
\hline \multirow[t]{6}{*}{2} & Field Location & Onshore & $5.0 \%$ \\
\hline & & Offshore $(0-20 \mathrm{~m})$ & $8.0 \%$ \\
\hline & & Offshore (21-50m) & $10.0 \%$ \\
\hline & & Offshore (51-150m) & $12.0 \%$ \\
\hline & & Offshore (150-1000m) & $14.0 \%$ \\
\hline & & Offshore (>1000m) & $16.0 \%$ \\
\hline \multirow[t]{2}{*}{3} & Reservoir Depth & $\begin{array}{l}<=2500 \mathrm{~m} \\
>2500 \mathrm{~m}\end{array}$ & $0.0 \%$ \\
\hline & & & $1.0 \%$ \\
\hline
\end{tabular}

\section{PROGRESSIVE SPLIT}

\begin{tabular}{|l|l|l|c|}
\hline & & \multicolumn{1}{|c|}{ Type of Incentive } & Additional Split \\
\hline 1 & Local Content & $<30 \%$ & $0.0 \%$ \\
\hline & & $30=<\mathrm{x}<50 \%$ & $2.0 \%$ \\
\hline & & $50=<\mathrm{x}<70 \%$ & $3.0 \%$ \\
\hline 2 & Oil Price & $70=<\mathrm{x}<100 \%$ & $4.0 \%$ \\
\hline & & $<40$ & $7.5 \%$ \\
\hline & & $40=<\mathrm{x}<55$ & $5.0 \%$ \\
\hline & & $55=<\mathrm{x}<70$ & $2.5 \%$ \\
\hline & & $70=<\mathrm{x}<85$ & $0.0 \%$ \\
\hline & & $85=<\mathrm{x}<100$ & $-2.5 \%$ \\
\hline & & $100=<\mathrm{x}<115$ & $-5.0 \%$ \\
\hline 3 & Commulative & $>=115$ & $-7.5 \%$ \\
\hline 4 & Supported Infrastructure & $<1 \mathrm{mmbee}$ & $5.0 \%$ \\
\hline & & Well Developed & $0.0 \%$ \\
\hline 5 & Reservoir Condition & New Frontier & $2.0 \%$ \\
\hline & & Conventional & $0.0 \%$ \\
\hline 6 & CO2 (\%) & Non Conventional & $16.0 \%$ \\
\hline & & $<5 \%$ & $0.0 \%$ \\
\hline & & $5=<\mathrm{x}<10 \%$ & $0.5 \%$ \\
\hline & & $10=<\mathrm{x}<20 \%$ & $1.0 \%$ \\
\hline & & $20=<\mathrm{x}<40 \%$ & $1.5 \%$ \\
\hline & & $40=<\mathrm{x}<60 \%$ & $2.0 \%$ \\
\hline 7 & H2S (ppm) & $\mathrm{x}>=60 \%$ & $4.0 \%$ \\
\hline & & $<100$ & $0.0 \%$ \\
\hline & & $100=<\mathrm{x}<300$ & $0.5 \%$ \\
\hline & & $300=<\mathrm{x}<500$ & $0.75 \%$ \\
\hline 8 & Oil Specific & $\mathrm{x}>=500$ & $1.0 \%$ \\
\hline
\end{tabular}




\begin{tabular}{|l|l|l|c|}
\hline & & \multicolumn{1}{|c|}{ Type of Incentive } & Additional Split \\
\hline & Gravity (API) & API $>25$ & $0.0 \%$ \\
\hline 9 & Production Phase & Primary & $0.0 \%$ \\
\hline & & Secondary & $3.0 \%$ \\
\hline & & Tertiary & $5.0 \%$ \\
\hline & Production & $1-10$ mmboe & $4.0 \%$ \\
\hline & & $10-20$ mmboe & $3.0 \%$ \\
\hline & & $20-50$ mmboe & $2.0 \%$ \\
\hline & & $50-150$ mmboe & $1.0 \%$ \\
\hline & & $>150$ mmboe & $0.0 \%$ \\
\hline
\end{tabular}

Note :

In case the field commercialization doesn't get to certain economic scale, Company will be get additional split $5 \%$ as maximum.

(Source: Ministerial Decree of MEMR No 8/2017 and No 52/2017) 
Appendix-B: The Potential Failure Cause Gross Split Implementation at Company

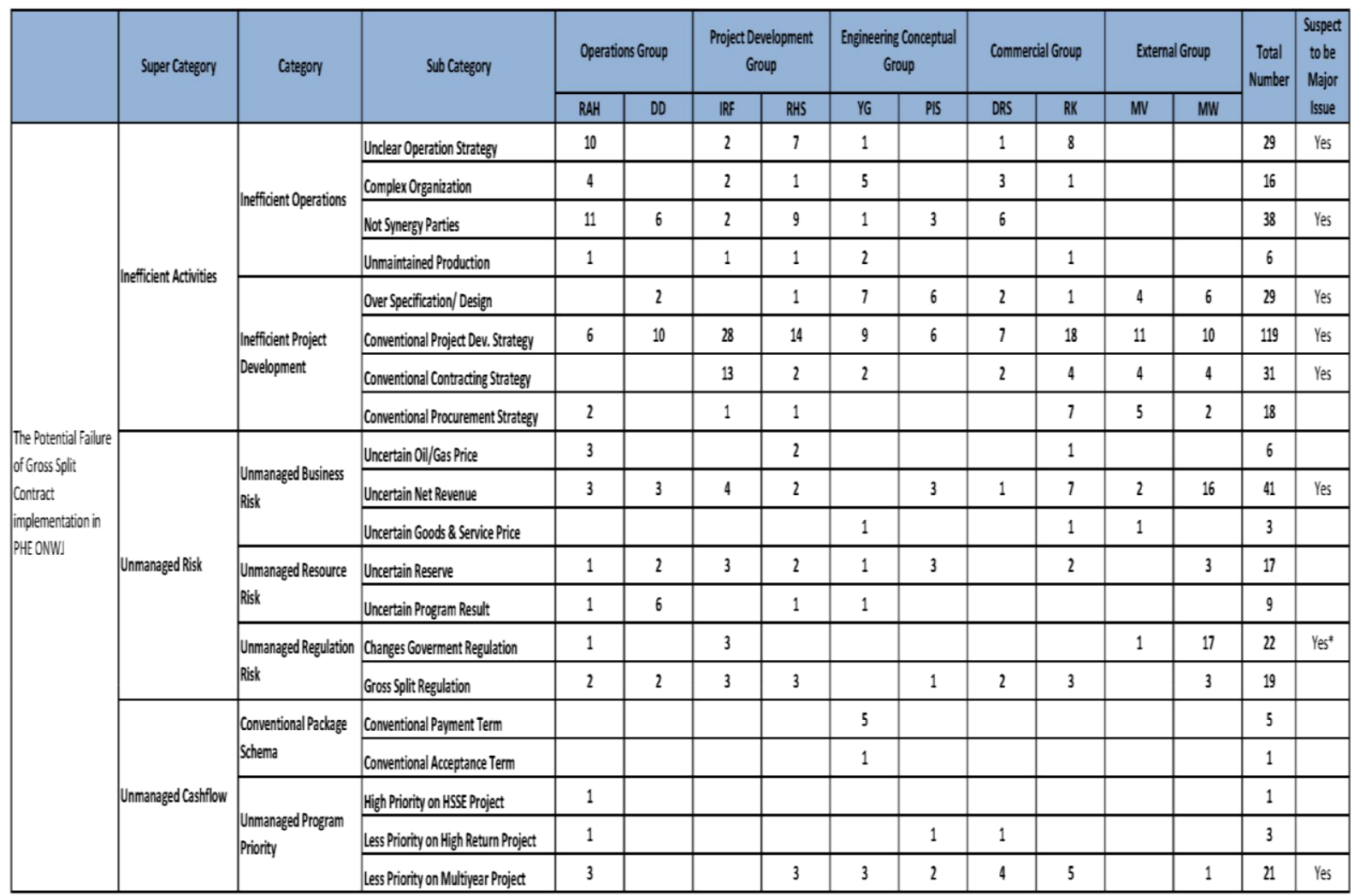

Appendix-C: The Major Issues

\begin{tabular}{|c|l|c|c|c|c|c|}
\hline \multirow{2}{*}{ No } & \multicolumn{1}{|c|}{$\begin{array}{c}\text { Important } \\
\text { issues }\end{array}$} & $\begin{array}{c}\text { Inefficient } \\
\text { Work } \\
\text { Program }\end{array}$ & $\begin{array}{c}\text { Negative } \\
\text { Cash } \\
\text { Flow }\end{array}$ & $\begin{array}{c}\text { Changes } \\
\text { Regulation }\end{array}$ & $\begin{array}{c}\text { Overa II } \\
\text { Level }\end{array}$ & $\begin{array}{c}\text { Issue } \\
\text { Category }\end{array}$ \\
\cline { 2 - 6 } & $\begin{array}{l}\text { Unclear } \\
\text { Operation } \\
\text { Strategy }\end{array}$ & High & High & Low & High & Major \\
\hline 2 & $\begin{array}{l}\text { Complex } \\
\text { Organization }\end{array}$ & Low & Medium & Low & Low & High \\
\hline 3 & $\begin{array}{l}\text { Not Synergy } \\
\text { Parties }\end{array}$ & High & High & Low & Major \\
\hline 4 & $\begin{array}{l}\text { Unmaintained } \\
\text { production }\end{array}$ & Medium & Medium & Low & Medium & \\
\hline 5 & $\begin{array}{l}\text { Over } \\
\text { Specification } \\
\text { Design }\end{array}$ & High & High & Low & High & Major \\
\hline 6 & $\begin{array}{l}\text { Conventional } \\
\text { Project Dev. }\end{array}$ & High & High & Medium & High & Major \\
\hline
\end{tabular}




\begin{tabular}{|c|c|c|c|c|c|c|}
\hline \multirow[b]{2}{*}{ No } & \multirow[b]{2}{*}{$\begin{array}{l}\text { Important } \\
\text { issues }\end{array}$} & \multicolumn{3}{|c|}{ Impact to Failure } & \multirow[b]{2}{*}{$\begin{array}{c}\text { Overa II } \\
\text { Level }\end{array}$} & \multirow[b]{2}{*}{$\begin{array}{l}\text { Issue } \\
\text { Category }\end{array}$} \\
\hline & & $\begin{array}{c}\text { Inefficient } \\
\text { Work } \\
\text { Program }\end{array}$ & $\begin{array}{c}\text { Negative } \\
\text { Cash } \\
\text { Flow }\end{array}$ & $\begin{array}{l}\text { Changes } \\
\text { Regulation }\end{array}$ & & \\
\hline & Strategy & & & & & \\
\hline 7 & $\begin{array}{l}\text { Conventional } \\
\text { Contracting } \\
\text { Strategy }\end{array}$ & High & High & Medium & High & Major \\
\hline 8 & $\begin{array}{l}\text { Conventional } \\
\text { Procurement } \\
\text { Strategy }\end{array}$ & Medium & High & Low & Medium & \\
\hline 9 & $\begin{array}{l}\text { Uncertain } \\
\text { oil/gas price }\end{array}$ & Medium & High & Low & Medium & \\
\hline 10 & $\begin{array}{l}\text { Uncertain Net } \\
\text { Revenue }\end{array}$ & High & High & Medium & High & Major \\
\hline 11 & $\begin{array}{l}\text { Uncertain } \\
\text { goods/service } \\
\text { Price }\end{array}$ & Low & High & Low & Medium & \\
\hline 12 & $\begin{array}{l}\text { Uncertain } \\
\text { reserve }\end{array}$ & Medium & Medium & Low & Medium & \\
\hline 13 & $\begin{array}{l}\text { Uncertain } \\
\text { Program result }\end{array}$ & High & Low & Low & Medium & \\
\hline 14 & $\begin{array}{l}\text { Changes } \\
\text { Government } \\
\text { Regulation }\end{array}$ & High & Low & High & High & Major \\
\hline 15 & $\begin{array}{l}\text { Gross Split } \\
\text { Regulation }\end{array}$ & Low & Low & High & Medium & \\
\hline 16 & $\begin{array}{l}\text { Conventional } \\
\text { Payment Term }\end{array}$ & Low & High & Low & Medium & \\
\hline 17 & $\begin{array}{l}\text { Conventional } \\
\text { Acceptance } \\
\text { Term }\end{array}$ & Low & High & Low & Medium & \\
\hline 18 & $\begin{array}{l}\text { High Priority } \\
\text { on HSSE } \\
\text { Project }\end{array}$ & High & Medium & Low & Medium & \\
\hline 19 & $\begin{array}{l}\text { Less Priority on } \\
\text { High Return } \\
\text { Project }\end{array}$ & Low & High & Low & Medium & \\
\hline 20 & $\begin{array}{l}\text { Less Priority } \\
\text { Multiyear } \\
\text { Project }\end{array}$ & High & High & Low & High & Major \\
\hline
\end{tabular}




\section{Appendix-D: Recommendations for Company and the Impact.}

\begin{tabular}{|c|c|c|c|c|c|c|}
\hline No & Major Issue & $\begin{array}{l}\text { Recommended } \\
\text { Strategy }\end{array}$ & $\begin{array}{l}\text { Previous } \\
\text { Activity }\end{array}$ & $\begin{array}{l}\text { Ongoing } \\
\text { Upcoming } \\
\text { Activity }\end{array}$ & $\&$ & $\begin{array}{l}\text { Impact and } \\
\text { Result }\end{array}$ \\
\hline 1 & $\begin{array}{l}\text { Unclear } \\
\text { Operation } \\
\text { Strategy }\end{array}$ & $\begin{array}{l}\text { COMPANY to } \\
\text { finish the } \\
\text { identification of } \\
\text { productive } \\
\text { assets and } \\
\text { return un- } \\
\text { productive } \\
\text { asset }\end{array}$ & $\begin{array}{l}\text { All asset } \\
\text { facilities still } \\
\text { remain to } \\
\text { operate by } \\
\text { COMPANY }\end{array}$ & $\begin{array}{l}\text { Select only } \\
\text { productive } \\
\text { asset that } \\
\text { will be } \\
\text { operated by } \\
\text { COMPANY }\end{array}$ & & $\begin{array}{l}\text { To reduce the } \\
\text { rental cost for } \\
\text { the asset }\end{array}$ \\
\hline 2 & $\begin{array}{l}\text { Unclear } \\
\text { Operation } \\
\text { Strategy }\end{array}$ & $\begin{array}{l}\text { COMPANY to } \\
\text { conduct a study } \\
\text { for the cheapest } \\
\text { decommissioni } \\
\text { ng scheme }\end{array}$ & $\begin{array}{l}\text { COMPANY } \\
\text { assumed the } \\
\text { decommissioni } \\
\text { ng method is } \\
\text { standard that } \\
\text { need high cost }\end{array}$ & $\begin{array}{l}\text { COMPANY } \\
\text { to have } \\
\text { new } \\
\text { method } \\
\text { with less } \\
\text { cost }\end{array}$ & & $\begin{array}{l}\text { Reducing the } \\
\text { cot of } \\
\text { decommissioni } \\
\text { ng the unused } \\
\text { facility }\end{array}$ \\
\hline 3 & $\begin{array}{l}\text { Not } \\
\text { Synergy } \\
\text { Parties }\end{array}$ & $\begin{array}{l}\text { COMPANY to } \\
\text { encourage the } \\
\text { government to } \\
\text { resolve } \\
\text { unfinished } \\
\text { regulations and } \\
\text { policies }\end{array}$ & $\begin{array}{l}\text { Communicate } \\
\text { and give } \\
\text { feedback to } \\
\text { government for } \\
\text { unfinished } \\
\text { regulation and } \\
\text { policies }\end{array}$ & No changes & & $\begin{array}{l}\text { Obtaining a } \\
\text { complete } \\
\text { guidance from } \\
\text { government } \\
\text { such as tax } \\
\text { regulation more } \\
\text { detail split } \\
\text { formula } \\
\text { calculation }\end{array}$ \\
\hline 4 & $\begin{array}{l}\text { Over } \\
\text { Specificatio } \\
\text { n Design }\end{array}$ & $\begin{array}{l}\text { COMPANY to } \\
\text { create new } \\
\text { specification } \\
\text { and new design }\end{array}$ & $\begin{array}{l}\text { Using high } \\
\text { specification } \\
\text { and new design }\end{array}$ & $\begin{array}{l}\text { Using new } \\
\text { *fit for } \\
\text { purpose } \\
\text { specificatio } \\
\text { n and new } \\
\text { design }\end{array}$ & & $\begin{array}{l}\text { Cheaper price } \\
\text { for material and } \\
\text { the service }\end{array}$ \\
\hline 5 & $\begin{array}{l}\text { Convention } \\
\text { al Project } \\
\text { Developme } \\
\text { nt Strategy }\end{array}$ & $\begin{array}{l}\text { COMPANY to } \\
\text { perform more } \\
\text { modeling of } \\
\text { development } \\
\text { project scenario } \\
\text { to find the most } \\
\text { optimum }\end{array}$ & $\begin{array}{l}\text { COMPANY } \\
\text { only perform a } \\
\text { limited } \\
\text { modeling of } \\
\text { project } \\
\text { development } \\
\text { scenario }\end{array}$ & $\begin{array}{l}\text { COMPANY } \\
\text { to perform } \\
\text { more } \\
\text { modeling } \\
\text { of project } \\
\text { developme } \\
\text { nt scenario }\end{array}$ & & $\begin{array}{l}\text { To have the } \\
\text { most effective } \\
\text { and efficient of } \\
\text { project } \\
\text { development } \\
\text { scenario }\end{array}$ \\
\hline
\end{tabular}




\begin{tabular}{|c|c|c|c|c|c|c|}
\hline No & Major Issue & $\begin{array}{l}\text { Recommended } \\
\text { Strategy }\end{array}$ & $\begin{array}{l}\text { Previous } \\
\text { Activity }\end{array}$ & $\begin{array}{l}\text { Ongoing } \\
\text { Upcoming } \\
\text { Activity }\end{array}$ & $\&$ & $\begin{array}{l}\text { Impact and } \\
\text { Result }\end{array}$ \\
\hline 6 & $\begin{array}{l}\text { Convention } \\
\text { al } \\
\text { Contracting } \\
\text { Strategy }\end{array}$ & $\begin{array}{l}\text { COMPANY to } \\
\text { propose an } \\
\text { umbrella } \\
\text { contract } \\
\text { involving all } \\
\text { others } \\
\text { subsidiaries }\end{array}$ & $\begin{array}{l}\text { COMPANY } \\
\text { only has } \\
\text { contract for } \\
\text { service and } \\
\text { goods that } \\
\text { cover } \\
\text { COMPANY } \\
\text { needs. }\end{array}$ & $\begin{array}{l}\text { COMPANY } \\
\text { and other } \\
\text { subsidiary } \\
\text { will have a } \\
\text { bigger } \\
\text { contract } \\
\text { that serves } \\
\text { all } \\
\text { subsidiaries } \\
\text { under } \\
\text { corporate } \\
\text { holding }\end{array}$ & & $\begin{array}{l}\text { To reduce the } \\
\text { unit rate price } \\
\text { of service and } \\
\text { material hence } \\
\text { the reducing } \\
\text { cost will } \\
\text { happened }\end{array}$ \\
\hline 7 & $\begin{array}{l}\text { Convention } \\
\text { al } \\
\text { Contracting } \\
\text { Strategy }\end{array}$ & $\begin{array}{l}\text { COMPANY to } \\
\text { encourage } \\
\text { government in } \\
\text { joint contract } \\
\text { service } \\
\text { involving some } \\
\text { companies }\end{array}$ & $\begin{array}{l}\text { COMPANY to } \\
\text { ask government } \\
\text { in joint contract } \\
\text { service } \\
\text { involving some } \\
\text { other } \\
\text { companies }\end{array}$ & No changes & & $\begin{array}{l}\text { To reduce the } \\
\text { risk and cost of } \\
\text { new investment } \\
\text { particularly in } \\
\text { exploration } \\
\text { activity (high) } \\
\text { risk, high (cost) }\end{array}$ \\
\hline 8 & $\begin{array}{l}\text { Uncertain } \\
\text { Net } \\
\text { Revenue }\end{array}$ & $\begin{array}{l}\text { COMPANY to } \\
\text { improve the } \\
\text { economic } \\
\text { analysis of the } \\
\text { project } \\
\text { development } \\
\text { strategy }\end{array}$ & $\begin{array}{l}\text { Analysis used } \\
\text { the existing } \\
\text { data without } \\
\text { verifying the } \\
\text { current real } \\
\text { condition }\end{array}$ & $\begin{array}{l}\text { Analysis } \\
\text { using the } \\
\text { existing } \\
\text { data and } \\
\text { verified } \\
\text { with } \\
\text { current real } \\
\text { condition }\end{array}$ & & $\begin{array}{l}\text { Increasing } \\
\text { confident level } \\
\text { of success in } \\
\text { project } \\
\text { development } \\
\text { investment }\end{array}$ \\
\hline 9 & $\begin{array}{l}\text { Change } \\
\text { Governmen } \\
\text { t Regulation }\end{array}$ & $\begin{array}{l}\text { COMPANY to } \\
\text { encourage } \\
\text { government } \\
\text { maintaining } \\
\text { contract } \\
\text { commitments } \\
\text { and maintain } \\
\text { consistency }\end{array}$ & $\begin{array}{l}\text { COMPANY to } \\
\text { advice } \\
\text { government in } \\
\text { maintaining } \\
\text { contract } \\
\text { commitments } \\
\text { for agreed } \\
\text { contract } \\
\text { without any } \\
\text { change } \\
\text { drastically }\end{array}$ & No changes & & $\begin{array}{l}\text { To secure } \\
\text { investor } \\
\text { business and } \\
\text { expectation }\end{array}$ \\
\hline
\end{tabular}




\begin{tabular}{|c|c|c|c|c|c|c|}
\hline No & Major Issue & $\begin{array}{l}\text { Recommended } \\
\text { Strategy }\end{array}$ & $\begin{array}{l}\text { Previous } \\
\text { Activity }\end{array}$ & $\begin{array}{l}\text { Ongoing } \\
\text { Upcoming } \\
\text { Activity }\end{array}$ & $\&$ & $\begin{array}{l}\text { Impact and } \\
\text { Result }\end{array}$ \\
\hline 10 & $\begin{array}{l}\text { Less } \\
\text { Priority } \\
\text { Multiyear } \\
\text { Project }\end{array}$ & $\begin{array}{l}\text { COMPANY to } \\
\text { do re-phase the } \\
\text { project } \\
\text { execution with } \\
\text { priority on the } \\
\text { most beneficial } \\
\text { project }\end{array}$ & $\begin{array}{l}\text { COMPANY } \\
\text { performed } \\
\text { project } \\
\text { execution in } \\
\text { parallel focused } \\
\text { on high return } \\
\text { project }\end{array}$ & $\begin{array}{l}\text { COMPANY } \\
\text { to } \\
\text { prioritizes } \\
\text { project } \\
\text { execution } \\
\text { with } \\
\text { pattern: } \\
\text { HSSE } \\
\text { Project, } \\
\text { High } \\
\text { Return } \\
\text { Project and } \\
\text { Low Return } \\
\text { Project }\end{array}$ & & $\begin{array}{l}\text { To maintain } \\
\text { COMPANY } \\
\text { reputation and } \\
\text { managing } \\
\text { positive cash } \\
\text { flow }\end{array}$ \\
\hline
\end{tabular}

